\title{
BIOENERGETIKA TÁRSADALMI, GAZDASÁGI ÉS KÖRNYEZETI KONTEXTUSBAN
}

\section{BIOENERGETICS IN THE CONTEXT OF SOCIETY, ECONOMY, AND ENVIRONMENT}

\author{
Némethy Sándor \\ PhD, egyetemi docens, Eszterházy Károly Egyetem Gyöngyösi Károly Róbert Campus, Göteborgi Egyetem Konzervációs Intézet \\ nemethy.sandor@uni-eszterhazy.hu
}

\section{ÖSSZEFOGLALÓ}

A megújuló energiarendszerek nélkülözhetetlen alkotóeleme, a bioenergetika már önmagában is sokrétű, és szorosan kapcsolódik a mezőgazdasághoz, az erdőgazdasághoz, a szennyvíztisztításhoz, a szilárd hulladékok energetikai felhasználásához és a szerves, komposztálható hulladékokat termelő iparágakhoz és szolgáltatásokhoz, melyek együttesen az antropogén eredetű ökociklusok egy jelentős részét alkotják. A biomassza-termelés, különösen az energiaültetvények elterjedése azonban óhatatlanul felveti az élelmiszertermelés és a biomassza előállítása közötti konfliktus kérdését, melyre a választ csak a komplex megújuló energiarendszerek létrehozásával adhatjuk meg, ahol a bioenergia lehet akár a legfőbb alkotóelem is, de nem kizárólagos energiafajta, hanem együtt jelenik meg a geotermikus energiával, a napelemekkel, a szélturbinákkal, vízierőművekkel és a környezetet nem szennyező, magas technológiai színvonalú hulladékégető berendezésekkel. Az ökológiai ciklusokra (ökociklusokra) épülő vidéki gazdaság megújulóenergia-termelő rendszereinek egymással és a különböző gazdasági tevékenységekkel egy rendszerben való összekapcsolása akár az „energia-trilemma" megoldásának kulcsa is lehet.

\section{ABSTRACT}

Bioenergetics is a multifaceted category of energy production, an indispensable component of renewable energy systems and is closely linked to agriculture, forestry, sewage treatment, energy utilization of solid wastes and organic, compostable waste producing industries and services, which together form a significant part of anthropogenic ecocycles. However, the proliferation of biomass production, especially energy crops, inevitably raises the issue of conflict between food production and biomass production, which can be solved only by the creation of complex renewable energy systems, where bioenergy can be the main constituent, but not the exclusive source of energy, which appears in one system together with geothermal energy, solar panels, wind turbines, hydroelectric power plants and high-tech, environment-friendly waste incineration plants. Combining renewable energy production systems of a rural economy based on ecological cycles with one another and with different economic activities in one system can be the key to solving the "energy trilemma". 
Kulcsszavak: bioenergia, biogeokémiai ciklusok, hulladék-energia programok, Hammarby-modell, mezőgazdasági energiarendszerek, körkörös gazdaság

Keywords: bioenergy, biogeochemical cycles, waste to energy programmes, Hammarby-model, agricultural energy systems, circular economy

\section{BEVEZETÉS}

A megújuló energiák forrásainak felfedezése, megtermelése, fenntartható hasznosítása sokkal komplexebb probléma, mint egyszerüen az emberiség energiaszükségletének kielégítése. Az energiatermelés és -felhasználás egyszerre több szinten valósul meg: beszélhetünk helyi, regionális, országos és globális energiarendszerekről és ezek helyéről a természetes földi rendszerekben, a természetes és mesterséges (antropogén) biogeokémiai ciklusokban. ${ }^{1}$ Ezeknek a különböző skálán müködő energiarendszereknek a gazdaságosságát, környezeti hatásait és az energiagazdálkodás szempontjából nélkülözhetetlen, az ökociklusokra épülö rendszerszemlélet gyakorlati aspektusainak társadalmi elfogadottságát mind figyelembe kell venni a regionális fejlesztési projektek megtervezésekor (Némethy-Dinya, 2012; Dinya, 2012).

A bioenergetika fontos szerepet játszik a fenntartható társadalom alapját képező körkörös gazdaságban (Némethy-Kömíves, 2016), amelynek környezettudományi alapkoncepciója a megújuló energia - késztermék - zéróhulladék-rendszer és az ökoszisztéma-szolgáltatások ${ }^{2}$ fenntartható hasznosítása. Ennek a rendszernek a müködését az életciklus-elemzésen ${ }^{3}$ alapuló árutermelés, az újrahasznosításra összpontosító hulladékgazdálkodás és a hulladékenergia-programok egyidejü alkalmazása biztosítja. Fontos figyelembe venni a megújuló energiafajták hasznosításánál a pluralitás elvét, amely ezen energiafajták egymást kiegészítő alkalmazását írja elő nem csupán gazdasági, de környezetvédelmi és energiabiztonsági szempontok miatt is. A bioenergetika már önmagában is sokrétü, és szorosan kapcsolódik a mezőgazdasághoz, az erdőgazdasághoz, a szennyvíztisztításhoz, a szilárd hulladékok energetikai felhasználásához és a komposztálható szerves hulladékokat termelö iparágakhoz és szolgáltatásokhoz. Ezekkel már létre is hoztuk

\footnotetext{
${ }^{1}$ Biogeokémiai ciklusok: Az élethez nélkülözhetetlen elemek és alkotórészek körforgását a biogeokémiai körfolyamatok biztosítják, amelyek energiaigényét közvetlenül vagy közvetve a napsugárzás fedezi.

${ }^{2}$ Ökoszisztéma alatt az élőlények és élettelen környezetük teljes kapcsolatrendszerét értjük. Ökoszisztéma-szolgáltatásnak nevezzük a természet azon javait és szolgáltatásait, amelyeket az emberek saját jólétük biztosításának érdekében felhasználnak.

${ }^{3}$ Az életciklus-elemzés (Life Cycle Assessment, LCA) egy folyamat, termék, illetve szolgáltatás teljes életútja során vizsgálja a környezetre gyakorolt potenciális hatásokat.
} 
az antropogén eredetü ökociklusok ${ }^{4}$ egy részét. A biomassza-termelés, különösen az energiaültetvények elterjedése azonban óhatatlanul felveti az élelmiszer-termelés és a biomassza elóállítása közötti konfliktus kérdését, amelyre a választ csak a komplex megújuló energiarendszerek létrehozásával adhatjuk meg, ahol a bioenergia lehet akár a legfóbb alkotóelem is, de nem kizárólagos energiafajta, hanem együtt jelenik meg a geotermikus energiával, a napelemekkel, a szélturbinákkal, vízi erőművekkel és nem környezetszennyező, magas technológiai színvonalú hulladékégető berendezésekkel. Ez egyben az „energia-trilemma” megoldásának kulcsa is lehet.

Biomassza természetesen nemcsak termesztett energianövényekböl származhat, hanem a mezőgazdasági és erdészeti melléktermékek, élelmiszeripari hulladékok és tágabb értelemben a szennyvíztisztító müvek magas szervesanyag-tartalmú üledéke is biomasszának tekinthetö, mivel ennek és a komposztálható szerves hulladékoknak együttes erjesztésekor biogáz állítható elö. Több hazai és nemzetközi ,jó gyakorlatot" is ismerünk, amelyek ezeket a rendszereket hasznosítják. Említésre méltó a svédországi Hammarby Sjöstad, az ökociklusokra épülő ökováros, amelyet Stockholm egyik legbarnább területéből „zöldítettek” ki, vagy a skót Findhorn ökofalu, amely nem csupán környezettechnológiai megoldásairól, hanem szociális rendszeréről és világhírủ oktatási tevékenységéröl is ismert.

Hazánk energiagazdálkodásának javítása, az energiafüggőség megszüntetése csak a megfelelő léptékü, mikroregionális fejlesztésekben megvalósuló komplex termelési és szolgáltatási struktúrák és az egymást kiegészítő megújuló energiarendszerek létrehozásával lehetséges (Dinya, 2012). Nálunk sokkal kedvezőtlenebb földrajzi adottságú országok sokkal kevésbé függenek az energiahordozók importjától, mint mi - ezen a függőségen lehet és kell is változtatni.

\section{A MEGÚJULÓ ENERGIAFORRÁSOK FAJTÁI ÉS SZEREPÜK A VILÁG ENERGIAELLÁTÁSÁBAN}

A megújuló energia termelése (különös tekintettel a bio-, nap-, víz-, szél- és geotermikus energiára) a fenntarthatóság minden fajtájának kulcsa, beleértve ebbe az ökológiai, gazdasági, szociális életképességet és a kulturális örökség fenntartható megőrzését és hasznosítását is. A globális megújuló energiatermelés és -felhasználás folyamatosan növekszik, de 2016-ban az eddigi legnagyobb, 161 gigawatt $(\mathrm{GW})$ kapacitásnövekedést mutatta. Ez azt jelenti, hogy a megújuló ener-

\footnotetext{
${ }^{4}$ A természetes önfenntartó ökológiai rendszerben müködő körfolyamatok (például: biogeokémiai ciklusok, vízciklus stb.).

${ }^{5}$ Energia-trilemma: az energiabiztonság, a szén-dioxid-kibocsátás csökkentése és az energiaárak.
} 
giák 2016-ban a teljes globális nettó energiatermelési kapacitásnövekedésnek (tehát a fosszilis és megújuló energiafajtákból együttesen származó növekedésnek) hozzávetőlegesen $62 \%$-át adták.

A megújuló energiafajták globális kihasználtságának mértéke különbözik (1. táblázat), ezt nem csupán technológiai, de rövid és hosszú távú gazdasági és politikai megfontolások és szociális feltételek is szabályozzák (REN21, 2017). Legnagyobb mértékben a fotovoltaikus (PV) napenergia-hasznosítás ${ }^{6}$ növekedett, a teljes újonnan beállított megújuló energiatermelési kapacitásnak mintegy $47 \%$-át adta, míg a szélenergia 34\%-ot, a vízi energia pedig 15,5\%-ot adott. Figyelembe kell venni azt a tényt is, hogy a különböző országok természeti erőforrásai, gazdasági és szociális feltételei eltérőek, ami azt is jelenti, hogy ha egy fejlesztés gazdaságilag, szociálisan és infrastrukturálisan lehetséges egy országban, az nem feltétlenül valósítható meg egy másikban. A megújuló energiafajták hasznosításának és az ellátás kapacitásának és földrajzi elterjedésének folyamatos növekedése elsősorban négy tényezőre vezethető vissza: (1) a megújulóenergia-technológiák árának jelentős csökkenése, (2) több országban növekvő kereslet, (3) a megújuló energiákat célzottan támogató politikai és gazdasági mechanizmusok és (4) nagy nemzetközi vállalatok és intézmények kötelezték el magukat, hogy megújuló forrásokból származó elektromos energiát vásároljanak. Ezen pozitív tendenciák ellenére a megújuló energiákra való átállás mértéke messze nem éri el azt a mértéket, amely biztosítaná a 2015-ös Párizsi Egyezményben ${ }^{7}$ rögzített célt, hogy a globális hömérséklet-emelkedést a legrosszabb esetben is $2{ }^{\circ} \mathrm{C}$ alatt (lehetőleg $1,5^{\circ} \mathrm{C}$ alatt) tartsák. Bár a rendelkezésre álló és egyre gyorsabban fejlődő technológiák ezt lehetővé tennék, vannak rövid távú gazdasági és politikai megfontolások és nem megfelelően kiegyensúlyozott támogatási rendszerek, amelyek ezt az átállást jelentősen megnehezítik. A politikai és gazdasági határozathozó képességet nagymértékben növelné a komplex rendszerben való gondolkodás, amely módosítja a megújuló energiákon alapuló energiaellátó rendszerek definícióját úgy, hogy az nem csupán a szigorúan vett (többnyire elektromos) energiatermelésre koncentrál, hanem magában foglalja az újrahasznosításra épülő hulladékgazdálkodást, a fütő- és hütőrendszereket, továbbá a transzportszektor üzemanyag-szükségletét is, kiterjed a különféle gazdasági szektorok közötti kapcsolatokra és a regionális fejlesztés, infrastruktúra-bővítés és nyersanyag-felhasználás kérdéseire is (Dinya, 2012).

\footnotetext{
${ }^{6}$ A kizárólag elektromos energiát termelő fotovoltaikus (PV) napelemek kezdték kiszorítani a direkt meleg vizet szolgáltató napkollektoros rendszert. A hibrid kollektorok (napelem+napkollektor) azonban egyesítik a két rendszer elönyös tulajdonságait.

${ }^{7}$ A 2015-ös ENSZ klímaváltozási konferenciát (2015 United Nations Climate Change Conference) a Párizs melletti Le Bourget településen tartották november 30. és december 12. között az ENSZ tagállamainak 95\%-os részvételével.
} 
1. táblázat. A megújuló energia indikátorainak globális összehasonlítása 2015-2016

\begin{tabular}{|c|c|c|c|}
\hline & & 2015 & 2016 \\
\hline \multicolumn{4}{|l|}{ Befektetés } \\
\hline $\begin{array}{l}\text { Új évi befektetés megújuló elektromos energiába } \\
\text { és üzemanyagokba }\end{array}$ & milliárd USD & 312,2 & 241,6 \\
\hline \multicolumn{4}{|l|}{ Elektromosenergia-termelés (URL1) } \\
\hline $\begin{array}{l}\text { Megújuló elektromosenergia-termelési kapacitás } \\
\text { (teljes, a vízenergia kivételével) }\end{array}$ & GW & 785,0 & 921,0 \\
\hline $\begin{array}{l}\text { Megújuló elektromosenergia-termelési kapacitás } \\
\text { (teljes, a vízenergiával együtt) }\end{array}$ & GW & 1856,0 & 2017,0 \\
\hline Vízenergia-kapacitás & GW & 1071,0 & 1096,0 \\
\hline Bioenergia-kapacitás & GW & 106,0 & 112,0 \\
\hline Éves bioenergia-termelés ${ }^{10}$ & TWh & 464,0 & 504,0 \\
\hline Geotermikus energiatermelő kapacitás & GW & 13,0 & 13,5 \\
\hline Fotovoltaikus (PV) napenergia-termelő kapacitás & GW & 228,0 & 303,0 \\
\hline Koncentrált naphőenergia (CSP) kapacitás ${ }^{11}$ & GW & 4,7 & 4,8 \\
\hline Szélenergia-kapacitás & GW & 433,0 & 487,0 \\
\hline \multicolumn{4}{|l|}{ Fütés / melegvíz-előállítás } \\
\hline Napkollektorok & GWh & 435,0 & 456,0 \\
\hline Bioenergia & GWh & 315,0 & 325,0 \\
\hline Direkt geotermikus energia & GWh & 22,0 & 23,2 \\
\hline \multicolumn{4}{|l|}{ Transzport } \\
\hline Etanol, éves termelés & milliárd liter & 98,3 & 98,6 \\
\hline Biodízel, éves termelés & milliárd liter & 30,1 & 30,8 \\
\hline Hidrogénezett növényi olajok (HVO) éves termelés & milliárd liter & 4,9 & 5,8 \\
\hline
\end{tabular}

${ }^{8}$ Módosítva a REN21 Global Status Report 2017 alapján.

${ }^{9}$ Elektromos energiatermelési kapacitás: a maximális elektromos energiamennyiség, amelyet egy generátor ideális feltételek mellett produkálni képes.

${ }^{10}$ Éves bioenergia-termelés: a bioenergiával működő generátorok együttes évi energiatermelése.

${ }^{11}$ Naphőerőművek, a Nap hőjével fejlesztenek forró gőzt, és azt turbinák segítségével alakítják elektromos árammá. Sivatagi környezetben különösen elönyösek (például Izraelben, a Negev-sivatagban). 
A rendszerszemléletnek át kell hatnia az infrastrukturális fejlesztéseket, az energiaellátás finanszírozását és a releváns politikai határozathozatali mechanizmusokat is. Ugyancsak kulcsfontosságú szempont, hogy az energiaszegénységben (következésképpen általános szegénységben vagy mélyszegénységben) élő több milliárd ember modern, megújulóenergia-forrásokra épülő energiaellátását biztosítsuk. Ez természetesen a lehető legrugalmasabb és energiahatékonyabb rendszerek kialakítását követeli meg úgy, hogy nem szükségszerüen a gyors, fosszilis energiahordozókra épülő gigantikus központi ellátórendszereket fejlesztjük ki, hanem a megfelelö skálájú, gyorsan mobilizálható, sok esetben helyi vagy regionális fenntartható energiarendszerek fejlesztésére helyezzük a hangsúlyt, ahol a megújuló energiaforrások leghatékonyabb kombinációjával lehetővé tesszük a mindenki számára hozzáférhető energiaellátást, beleértve ebbe az elektromos energiát, a fütést és a hütést is. Ezekben a rendszerekben a bioenergia hasznosítása jelentős szerepet játszhat, különös tekintettel a fent említett holisztikus rendszerszemléletre.

\section{A BIOMASSZA DEFINIÍCIÓJA ÉS FORRÁSAI, A BIOMASSZÁBÓL VALÓ ENERGIANYERÉS LEHETŐSÉGEI ÉS KORLÁTAI}

Az Európai Unió 2009/28/CE direktívája alapján a biomassza „,a mezőgazdaságból (a növényi és állati eredetü anyagokat is beleértve), erdőgazdálkodásból és a kapcsolódó iparágakból - többek között a halászatból és az akvakultúrából - származó, biológiai eredetü termékek, hulladékok és maradékanyagok biológiailag lebontható része, valamint az ipari és települési hulladék biológiailag lebontható része". ${ }^{12}$ Eredetét tekintve a biomassza fogalma lényegében a napenergia kémiai energiává való átalakítására, a fotoszintézis útján szervetlen alkotóelemekből elöállított szerves anyagra vezethető vissza, amely természeténél fogva megújuló. Földünket évente $2,6 \times 10^{24} \mathrm{~J}$ napenergia éri, amelynek csupán $2 \%$-e alakul át fotoszintézis révén $5,7 \times 10^{2} \mathrm{~J} /$ év energiaértékü biomasszává, amely a fotoszintézisből származó elméleti biomasszakészletet adja. Nem szabad figyelmen kívül hagyni azonban, hogy a biomassza-termelés elsődleges célja az élet fenntartása, és csupán meghatározott része fordítható energetikai célokra. Bár a biomasszából származó megújuló energia végső soron napenergia, a biomassza fogalma mégsem teljesen egységes, ha figyelembe vesszük a már megtermelt, energetikai felhasználásra alkalmas szerves anyagok sokféleségét. A biomasszát eredete szerint a következő kategóriákba sorolhatjuk:

1. Elsődleges biomassza: a természetes elődleges produkció (fotoszintézis) során, autotróf szervezetek tevékenységéből származik: természetes vegetá-

${ }^{12}$ Az Európai Unió 2009/28/EC direktívájának 2. cikke. 
ció, szántóföldi növények, erdő, rét, legelő, kertészeti növények, vízben élő növények.

2. Másodlagos biomassza: a heterotróf szervezetek által elóállított szerves anyagok, az állatvilág, gazdasági haszonállatok, az állattenyésztés főtermékei, melléktermékei, hulladékai.

3. Harmadlagos biomassza: az elsődleges és másodlagos biomasszára épülő ipari tevékenység termékei, melléktermékei, hulladékai, emberi települések szerves eredetű hulladékai.

Kétségtelen, hogy a biomassza termelése és energetikai hasznosítása elsősorban a mezőgazdasághoz, a mezőgazdasági termények feldolgozásához és felhasználásához, továbbá az ezzel összekapcsolható hulladékgazdálkodáshoz köthető. A mezőgazdasági müvelés alatt álló területek a Föld felszínének 37\%-át foglalják el. A mezőgazdaság az antropogén metánkibocsátás 52\%-áert és a metánkibocsátás $84 \%$-áért felelős. Ezen üvegházi gázok redukciójának legelőnyösebb módja a foszszilis energiahordozók kiváltása mezőgazdasági bioenergia-forrásokkal (például: terménymaradványok, állati trágya, bioenergia-növények). A mezőgazdaságban lehetőség van kombinált termelési rendszerek kifejlesztésére, amelyek magukban foglalják a biotermelést, a bioenergia-erdők és más bioenergia-növények bioszürőként való használatát, a biológiailag tisztított, nehézfémektől mentes szennyvíz tápoldatként való alkalmazását és biogáz elóállítását a szennyvíziszapnak a fermentálható szerves hulladékkal való együtt erjesztése révén. A bioenergia-növények növelik a talaj szén-dioxid-visszatartó képességét, ezzel is hozzájárulva a globális felmelegedés csökkentéséhez. Ilyen módon lehetővé válik teljes ökológiai körfolyamatok létrehozása, amelyek minden energiaforrást optimálisan hasznosítanak, és minimumra csökkentik a hulladékok keletkezését, hosszú távon feleslegessé válhatnak a hulladéklerakó telepek, de legalább számuk jelentős csökkentése reális cél lehet. Biomassza tehát több forrásból nyerhető, de a bioenergia-potenciál növelésének lehetőségeit - a mezőgazdasági és környezetvédelmi szempontok elsődlegességének figyelembevételével - jelentősen befolyásolja, hogy a különféle biomasszaforrásokat milyen müszaki megoldásokkal, energetikai és gazdasági hatékonysággal lehet a megújulóenergia-ellátás megfelelően méretezett rendszereiben hasznosítani. Ez egyben azt is jelenti, hogy már a hasznosítható biomassza forrásainak azonosításánál is rendszerben kell gondolkodni, figyelembe véve az egymást kiegészítő források hasznosításának gazdasági potenciálját, mint például a szennyvíztisztítás és a biogáztermelés összekapcsolása, ami a szennyvíziszap veszélyes hulladékként való költséges kezelését nyereséges gazdasági tevékenységgé változtathatja.

A biomasszában elraktározott energia kinyerésének módját elsősorban az adott nyersanyag összetétele határozza meg, ami viszont annak eredetére vezethető vissza. A biomassza hasznosításának technológiái azonban sok esetben kiegészíthetik egymást, garantálva ezzel az energiatermelés gazdaságosságát is (1. ábra). 


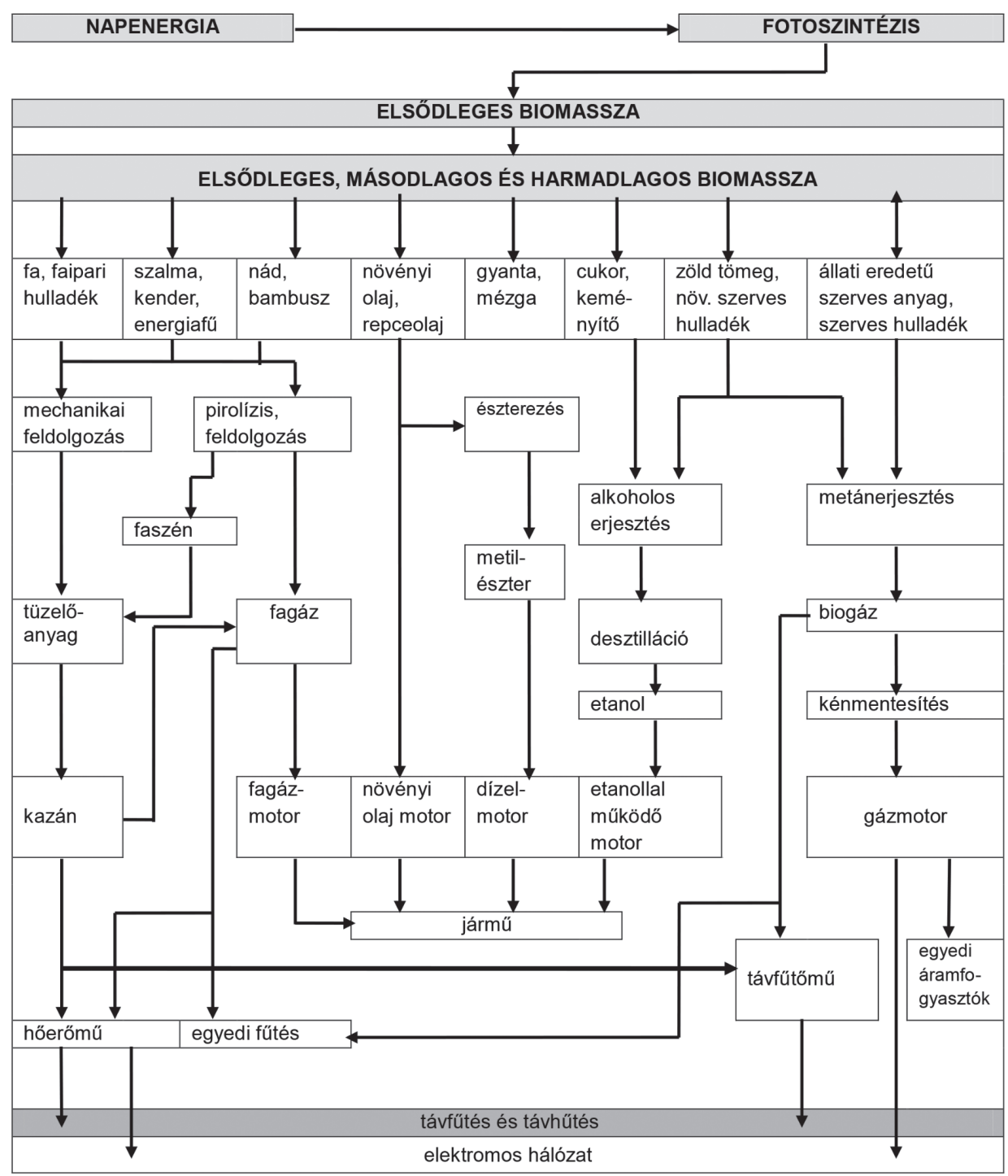

1. ábra. A biomassza típusai és a biomasszában elraktározott energia kinyerésének módjai. Az elsődleges biomasszának egy része direkt felhasználható energiatermelésre, de nagyon lényeges a másodlagos és harmadlagos biomassza is, mivel esetenként önmagukban nem gazdaságos energiatermelési rendszereket gazdaságossá tehetnek (például a hulladékot energiává alakító rendszerek). Saját szerkesztés Tóth et al., 2011 felhasználásával

A biomassza különböző formái megfelelő ipari feldolgozás révén a fosszilis energiahordozókkal egyenértékű energiahordozókká alakíthatók, amelyekből hő, villanyáram, valamint a közlekedés számára bioüzemanyag nyerhető. 
A részleges vagy esetenként teljes energiafüggetlenség mikroregionális szintü, megújuló energiákra épülő megvalósításában a bioenergia fontos szerepet játszik úgy, hogy a megújuló energiafajták koordinált, egy rendszerben történő hasznosításának részét képezi, figyelembe véve a bioenergia-hordozók megtermelésének és felhasználásának korlátait. A fenntarthatóság egyik legfontosabb alapelve, hogy az energia lehető legnagyobb részét a termelési és fogyasztási rendszerekből nyerjük ki, szem előtt tartva az élelmezésre és takarmányozásra fordítható elemek újrahasznosítását. A bioenergia megtermelésének és hasznosításának egyik legalapvetőbb korlátozó tényezője az értékes mezőgazdasági területek élelmiszer-termelésre való hasznosítása, tehát a bioenergia-ültetvényeket olyan területekre kell korlátozni, amelyek nem alkalmasak élelmiszer-termelésre vagy kimondottan talajjavítást (fitoremediáció) ${ }^{13}$ igényelnek, amelyre bizonyos energianövények különösen alkalmasak. Bioenergia tehát csak akkor alkalmazható, ha az adott források nem tesznek magasabb értékü felhasználást lehetővé (Marquis-Trans, 2008). Az elsődleges biomassza termelésére épülő bioenergia hasznosíthatósága tehát korlátozott, de a másodlagos és harmadlagos bioenergia-hordozók hasznosítása és az egyéb megújuló energiafajtákkal való együttes alkalmazása alkalmas lehet arra, hogy teljes mértékben kiváltsa a fosszilis energiahordozókat. Egy másik lényeges szempont az, hogy az elsődleges biomassza eredetü energiaforrások területegységre vetített szárazanyaghozama (t/ha), illetve az ennek megfelelö bruttó, nettó energiahozam (tOE/ha) a hagyományos kultúrák esetében meglehetősen mérsékelt (1,5-3,5 t/ha, 0,3-1,3 tOE/ha) ${ }^{14}$. A célirányos biomassza-termelésnek vannak ugyan korlátai, de az előbb említett értékek a genetikai szelekció és az agrotechnikai eljárások fejlödésének köszönhetően jelentősen növelhetők, energiaerdők és az energetikai növények termesztése esetében akár 8-9 t/ha, illetve 1,7-2,6 tOE/ha értékig emelhetők (Tóth et al., 2011).

\section{A BIOENERGIA-TERMELÉS INTEGRÁCIÓJA ÉS A FENNTARTHATÓ HULLADÉKGAZDÁLKODÁS}

A bioenergia-termelés integrációja természetesen a termelési tevékenységek és szolgáltatások egy rendszerben való kezelését is feltételezi. Lényeges, hogy mind a mezőgazdasági, mind az ipari termelés a természetes ökológiai ciklusok fenntartására és az ökoszisztéma-szolgáltatások fenntartható használatára épüljön, figyelembe véve a kultúrtájak védelmének szempontjait is (Némethy-Wałas, 2016). Ide tartozik a hulladékok energetikai hasznosítása, ahol a legnyilvánvalóbb energianyerési mód a hulladékégetés, a hulladékok hő és villamos energia előállításá-

\footnotetext{
${ }^{13}$ A fitoremediáció alapja a növények szennyező anyagokat felvevő, akkumuláló, átalakító vagy lebontó képessége.

${ }^{14}$ tOE/ha: tonna olajekvivalens hektáronként.
} 
ra történő felhasználása. Ennek egyik legjelentősebb alkalmazása Magyarországon a cementgyárak (Vác, Beremend) üzemeltetése, ahol a költséges fütőanyagok hulladékokkal történő kiváltása jelentősen csökkenti az elöállított cement piaci árát. A másik fontos felhasználási terület a hulladékégető erőmüvekben történő égetés, amely közvetlenül hőenergiát és elektromos energiát szolgáltat.

A pirolízis, a szerves hulladékok hőbontása megfelelően kialakított reaktorban, hő hatására, oxigénszegény vagy oxigénmentes közegben szabályozott körülmények között történik. A folyamat során keletkező végtermékek elsősorban energiahordozóként (fütőgáz, tüzelöolaj, koksz), vegyipari másodnyersanyagként (például a gázterméket szintézisgázzá konvertálva metanol előállításához) és esetenként egyéb célokra (talajjavításra is használható bioszén ${ }^{15}$, fakonzerválás vizes maradékkal; granulált salakolvadék építőipari adalékanyagként stb.) hasznosíthatók.

A hulladékégetéssel történő energiatermelésnek lehetnek környezetkárosító hatásai. Ezek csak egy komplex rendszer kialakításával küszöbölhetők ki, amely magában foglalja a környezettudatos árutermelést, a termékválasztást és a hulladékok differenciált kezelését, szortírozását és újrahasznosítását. A helyesen és rendszeresen alkalmazott életciklus-analízis, a megfelelő termékszerkezet kialakítása, a helyes termékválasztás (környezettudatos vásárlás) és a fejlett hulladékszortírozási rendszerek következtében keletkező hulladék legnagyobb része újra felhasználható, míg az égethető hulladékfrakció megfelelő égetési és füstgáztisztítási technológiával akár a megtermelt biomasszával (például faaprítékkal és brikettel) együtt is, egy rendszerben hő- és elektromos energiává alakítható (Tóth et al., 2011).

A bioenergia-termelés és a hulladékgazdálkodás összekapcsolásának másik nagyszerű példája a biogáz előállítása a szennyvíztisztítás során keletkező szennyvíziszap, az élelmiszeripari szerves hulladék, a településekről származó komposztálható szerves háztartási hulladék, a magas nedvességtartalmú mezőgazdasági növényi hulladék, továbbá az állati trágya metánerjesztése révén. A keletkező metángáz (biogáz) bevezethető a gázhálózatba (Baldwin, 2008), de jelentős mennyiségü kénhidrogént is tartalmaz, amit üzemanyagként való felhasználása előtt el kell távolítani (kénmentesítés). A többi megújuló energiaforrás (geotermikus, víz-, szél-, napenergia) egy rendszerben történő együttes hasznosítása végső soron a vidéki települések energia-önellátását eredményezheti (2. ábra).

A több skálán müködő, fenntartható vagy direkt ökológiai (bio-), késztermék-orientált és teljes termékszerkezetre épülő mezőgazdasági termelés létreho-

\footnotetext{
${ }^{15}$ A bioszén (biochar) nagy széntartalmú, finomszemcsés, porózus anyag, amely a biomassza termokémiai bontása (pirolízis) során keletkezik oxigénhiányos környezetben és aránylag alacsony hömérsékleten $\left(<700^{\circ} \mathrm{C}\right)$.
} 


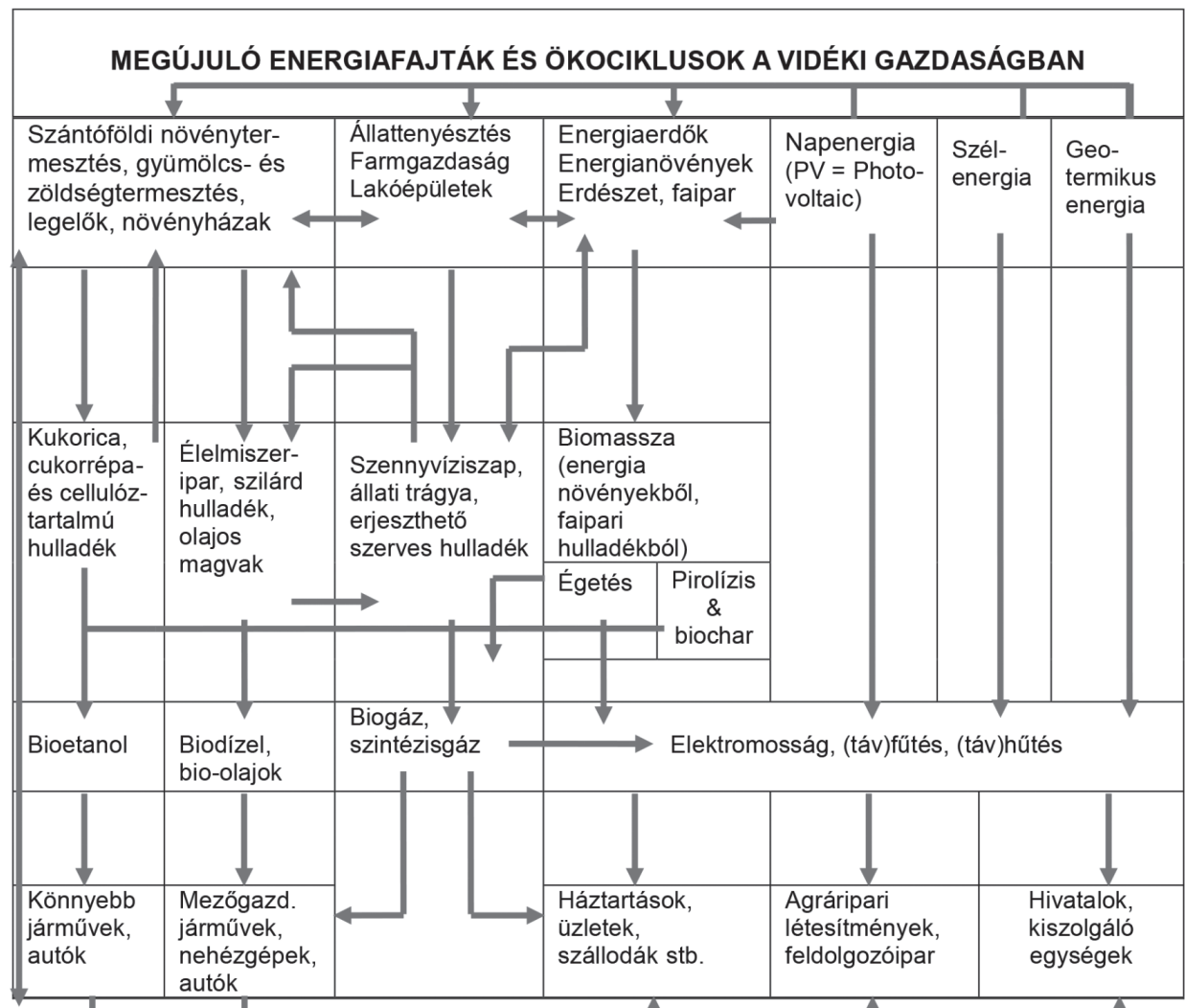

2. ábra. Az ökológiai ciklusokra épülő vidéki gazdaság energiatermelő rendszereinek egymással és a különböző gazdasági tevékenységekkel való kapcsolatai. Saját szerkesztés

zása, beleértve ebbe a családi kisgazdaságokat, a szövetkezetek különféle formáit, a permakultúrás gazdálkodást, az akvapóniát és a precíziós biogazdálkodást is, biztosíthatja a teljes mértékben megújuló energiaellátásra való áttérés ökológiai, gazdasági és szociális feltételeit. A magas munkaerőigényü ökológiai termelésre való áttérés és annak bioenergia-produkcióval való összekapcsolása lehetséges, ennek ideális feltételei adottak Magyarországon. Az ökológiai mezőgazdaság (biogazdálkodás) esetében is vannak fokozatok a munkaerőigény, a tevékenység energiahatékonysága, a vizekre és a környezetre gyakorolt hatása szempontjából. Az alacsony bevitelü fenntartható mezőgazdaság elveinek alkalmazása révén a kisléptékü élelmiszer-termelés során a környezet terhelése a lehető legkisebb mértéküre csökken. A modell, megvalósulásának végső formájában, semmilyen tevékenységének fenntartása érdekében nem használ semmilyen külső, nem megújuló energiát, hanem csupán az adott mezőgazdasági területen megtermelt bio- 
masszát, energiaerdőt, napenergiát és egyéb alternatív megoldásokat, bár ezek kézi munkaeröigénye lényegesen nagyobb, mint a hagyományos termelési formákban. A megnövekedett kézi munkaerő költsége kompenzálható a fent említett megújuló energiaellátás révén nyert költségmegtakarítással.

\section{IRODALOM}

Baldwin, J. (2008): The Benefits of Biomethane to Grid. Proceedings of Claverton Energy Conference, UK

Dinya L. (2012): The Green Local Economy. International Journal of Business Insights and Transformation, 5, 84-91.

ENER-SUPPLY Project (2012): A megújuló energiaforrások kézikönyve. Környezettudományi központ, http://www.ktk-ces.hu/ENER-SUPPLY/megujulo_kezikonyv_kicsi.pdf

Marquis, M. - Trans, P. (2008): Carbon Crucible. Science, 320, 5875, 460-461. DOI: 10.1126/ science. 1156451

Némethy S. - Dinya L. (2012): Sustainable Energy Management as a Prerequisite for Sustainable Tourism and Rural Development. Environmental, Economical and Social Implications. Sucha Beskidzka, Poland: Zeszyty Naukowe WSTiE, 68-91.

Némethy S. - Kömíves T. (2016): On Ecocycles and Circular Economy. Ecocycles, 2, 2, 1-2. DOI: 10.19040/ecocycles.v2i2.57, http://real.mtak.hu/39427/1/55 467_6_PB u.pdf

Némethy S. - Wałas, B. (2016): Bioenergy Crops as New Components of Rural and Agricultural Landscapes: Environmental and Social Impact, Conservation, Cultural Heritage and Economy. Journal of Central European Green Innovation, (JCEGI 3(TI)) HU, http://ageconsearch.umn. edu/record $/ 229424$

REN21 (2017): Global Status Report. Paris: REN21 Secretariat, http://www.ren21.net/wp-content/ uploads/2017/06/17-8399_GSR_2017_Full_Report_0621_Opt.pdf

Tóth P. - Bulla M. - Nagy G. (2011): Energetika. Digitális tankönytár. http://www.tankonyvtar.hu/ hu/tartalom/tamop425/0021_Energetika/ch04s02.html

URL1: https://www.eia.gov/tools/faqs/faq.php?id=101\&t=3 